\title{
Quality of Life and Housing
}

\author{
D. Streimikiene
}

\begin{abstract}
The increase of the quality of life is the main aim of sustainable development. The quality of life is being assessed by applying various dimensions, various indicators. The housing dimension is one of the major issues affecting the quality of life. The housing indicators reflecting the quality of life can be assessed by applying quality of housing, quality of housing environment and housing cost burdens indicators. The paper presents the concept of assessment of housing dimension in the quality of life index and the main indicators relevant to this dimension of quality of life.
\end{abstract}

Index Terms-Quality of life, housing quality, housing environment, housing expenditures burden, assessment.

\section{INTRODUCTION}

The quality of life can be used as the most general aim of sustainable development as this aim represents the economic, social and environmental dimensions of sustainable development. In this term it is important to assess the quality of life by evaluating the economic, social and environmental indicators related to quality of life [1], [2].

Indicators are very useful tool to develop policies and monitor the effectiveness and results achieved by these policies. Indicators are tools that measure, simplify and communicate important issues and trends. They can help people understand the essence of sustainable development issues and the relationships between them. Indicators are useful means of measuring progress, but also valuable tool to raise awareness of the key issues among the public and policy-makers, and to help people understand what they themselves need to do.

The term quality of life is used to evaluate the general well-being of individuals and societies. As this is the key issue of sustainable development it is very important to develop the system of measurement of quality of life. The term of quality of life is used in a wide range of contexts, including the fields of international development, healthcare, environment and politics. Quality of life should not be mixed with the concept of standard of living, which is based primarily on income [3], [4].

The standard indicators of the quality of life usually include not only wealth and employment, but also the built environment, physical and mental health, education, recreation and leisure time, crime rate and social belonging. Also the quality of life is tightly related with such issues as freedom, human rights, and happiness [5], [6]. Since the quality of life is a complex phenomenon and many of its determinants are strongly correlated with each other,

Manuscript received January 11, 2014; revised March 27, 2014.

D. Streimikiene is with Mykolas Romeris University, Faculty of Economics and Finance management, Ateities str. 20, LT-80303, Vilnius, Lithuania (e-mail: daliastreimikiene@mruni.eu). assessing the quality of life requires a comprehensive framework that includes a large number of components and allows assessing how their interrelations shape people's lives.

The concept of housing conditions is very broad and encompasses both the dwelling's physical attributes and satisfaction with housing. Overall, if housing conditions are good on one hand the high housing costs on the other side constitute a major concern for households in many countries [6], [7].

In general, having satisfactory accommodation is one of the most valuable aspects of people's lives and it is a major element of people's material living standards. It is essential to meet basic needs, such as for shelter from weather conditions, and to offer a sense of personal security, privacy and personal space. Good housing conditions are also essential for people's health and affect childhood development. As housing costs make up a large share of the household budget and constitute the main component of household wealth. There are no core set of housing indicators and there is need for more comparable data in this field. Everyone has the right to adequate housing, which means more than just four walls and a roof over one's head. Housing is essential to meet basic needs, such as being sheltered from extreme weather and climate conditions. Housing should offer people a suitable place to sleep and rest, where they are free of risks and hazards. In addition, housing should give a sense of personal security, privacy and persona space. Finally, housing is important to satisfy other essential needs, such as having a family. All these elements make a "house" a "home" and are intrinsically valuable to people.

The aim of the paper is to define the concept of assessment of housing the quality of life index and to define the main indicators for assessment of housing impact on quality of life. The main tasks of the paper: to define the trends of housing indicators in Lithuania and to compare them with the same indicators in old EU member states and neighboring countries and to develop policy recommendations. The comparative analysis and development of indicators approach was applied in the paper. The statistical data was collected from EUROSTAT database.

\section{Housing INDiCATORS RELATED to QUALITY OF LIFE}

Measuring housing conditions and their effects on people's well-being is a complex task because there are very few comparable indicators [8]. An ideal set of indicators to measure housing conditions should provide information about both the physical characteristics of the dwelling (e.g. availability of electricity, water supply, indoor flushing toilets, bathroom requirements, cooking facilities, the quality of materials and construction and whether parts of the 
dwelling are deteriorated or damaged) and the broader environmental characteristics of the areas where the dwellings are located (e.g. exposure to noise, indoor pollution, etc.). However housing costs make up a large share of the household budget, and low income population is often constrained by the level of resources left for other essential expenditures, such as food, healthcare and education. High housing costs can thus threaten households' material well-being and economic security. They may also generate forms of housing stress that may seriously hamper relations between households' members and impair the development of children. In Table I the housing indicators relevant to quality of life is being presented.

TABLE I: THE HOUSING INDICATORS RELEVANT TO QUALITY OF LIFE

\begin{tabular}{|c|c|c|c|c|}
\hline Dimensions & \multicolumn{4}{|c|}{ Indicators } \\
\hline Housing quality & $\begin{array}{l}\text { Overcrowding } \\
\text { rate, } \%^{2}\end{array}$ & $\begin{array}{l}\text { Housing } \\
\text { deprivation rate by } \\
\text { number of item, \% }\end{array}$ & $\begin{array}{l}\text { Share of total population } \\
\text { considering their dwelling as } \\
\text { too dark, } \%\end{array}$ & $\begin{array}{l}\text { Share of population satisfied with } \\
\text { housing quality, } \%\end{array}$ \\
\hline Housing environment & $\begin{array}{l}\text { Crime, violence or } \\
\text { vandalism in the } \\
\text { area, } \%\end{array}$ & $\begin{array}{l}\text { Noise from } \\
\text { neighbours or } \\
\text { from the street, \% }\end{array}$ & $\begin{array}{l}\text { Pollution, grime or other } \\
\text { environmental problems, } \%\end{array}$ & $\begin{array}{l}\text { The share of population satisfied with } \\
\text { housing environment, } \%\end{array}$ \\
\hline $\begin{array}{l}\text { Housing expenditures } \\
\text { burden }\end{array}$ & $\begin{array}{l}\text { The housing cost } \\
\text { overburden rate, } \%\end{array}$ & $\begin{array}{l}\text { Inability to keep } \\
\text { home adequately } \\
\text { warm, \% }\end{array}$ & $\begin{array}{l}\text { The share of housing costs in } \\
\text { disposable household income, } \\
\text { cost, \% }\end{array}$ & Inability to pay utility bills, $\%$ \\
\hline
\end{tabular}

As one can see from information provided in Table I the main indicators of housing consists of three main groups of indicators addressing the most important issues of housing having impact on quality of life.

\section{Housing QuALITY}

One major element of the quality of housing conditions is the availability of sufficient space in the dwelling. The main indicator that has been developed to describe space problems is the overcrowding rate, which assesses the proportion of people living in an overcrowded dwelling, as defined by the number of rooms available to the household, the household's size, as well as its members' ages and family situation.

This indicator provides information on housing overcrowding, which has long been identified as a major housing problem (Myers et al., 1996). Having sufficient space is essential to meet people's basic need for privacy and for making home a pleasant place to be. Too many tenants in a dwelling may also have a negative impact on children's health or school performance.

This indicator suffers from a number of limitations. First, it does not take into account the possible trade-off between the size of the dwelling, the proximity of public services such as schools and hospitals) also matters to people's well-being. Sometimes households choose to live in smaller houses or apartments located in better serviced areas, rather than in larger homes located in poorer neighborhoods. Second, an ideal indicator of the available space per person in a dwelling would refer not just to the number of rooms available but also to their overall size (e.g. the number of square meters per person). The size is largely influenced by the age and gender composition of the household; for example, a couple with two teenage children of different gender will have different needs in terms of available space than a couple with two young kids of around the same age. Eurostat has developed an indicator of overcrowded conditions that tries to overcome some of these shortcomings.

Housing quality can also be assessed by looking at other housing deficiencies, such as lack of certain basic sanitary facilities in the dwelling (such as a bath or shower or indoor flushing toilet) and problems in the general condition of the dwelling (leaking roof or dwelling being too dark).

The housing deprivation rate is the indicator providing assessment of selected housing deficiencies. The focus is on the lack of facilities for personal hygiene, as this is clearly detrimental to individuals' health and dignity. This indicator sheds light on the quality of the accommodation and provides a proxy measure of the notion of "decent housing".

Two basic facilities are considered here: indoor flushing toilets (measured as the percentage of people not having an indoor flushing toilet for the sole use of the household) and bathrooms (measured as the percentage of people having neither a bath nor a shower). The notion of "decent housing" includes other basic aspects of housing conditions, such as the quality of the roofs, floors, doors and window frames, which may also have adverse effects on people's health conditions and comfort.

The other indicator - the share of population considering their dwelling as too dark is being calculated by EUROSTAT and provides important information on living conditions.

The share of population satisfied with housing quality is perceived indicator and also useful for assessment of quality of life related to housing. The housing satisfaction may be defined as the "perceived gap between a respondent's needs and aspirations and the reality of the current residential context" [9]. There is evidence that people evaluate their satisfaction with housing relative to other persons, their own past experience and expectations for the future. This subjective indicator is therefore useful for capturing possible discontent with housing conditions in relation to unobservable circumstances that are not captured by the previous objective indicators. This indicator captures the extent to which people's perceived needs for housing services are met in practice.

This indicator relies on the following question: "Are you satisfied or dissatisfied with your current housing, dwelling, or place you live?" with responses grouped into two categories (satisfied or dissatisfied). Reported individual housing satisfaction can be used as an ordinal measure of true housing satisfaction [10]-[14], although cultural norms may influence people's perception of satisfactory housing. While 
these data are available for all OECD countries there are other methodological shortcomings therefore this indicator have to be taken with caution. This indicator is not being assessed by EUROSTAT.

Recent studies on quality of life indicators revealed that access to green spaces is essential for quality of life, as an unspoiled environment is a source of satisfaction (Balestra, Sultan (2012), improves mental well-being (Brown and Grant, 2007), allows people to recover from the stress of everyday life (Brajša-Žganec, Merkaš, Šverko, 2011), and to perform physical activity. Cross-sectional studies find that levels of physical activity are higher and obesity is lower in areas with higher levels of greenery (Reto, Garcia-Vega, 2012).

\section{HOUSING ENVIRONMENT}

Housing quality depends not only on the quality of the dwelling itself, but also on the wider residential area. In this case the indicators rely on the subjective opinion of the respondents, but have the advantage of drawing a more complete picture of housing. In 2011, $19.9 \%$ of EU-27 population lived in a dwelling where noise from neighbors or from the street was perceived as a problem. Over $30 \%$ of people in Malta were concerned with noise, followed by Romania (28.0\%), Cyprus (27.2\%), Germany (25.8\%) and Greece $(25.1 \%)$. At the other extreme, the rates were lowest in Hungary (9.8 \%), Bulgaria (12.2\%) and Estonia (12.7\%).

The indicator measuring the share of population exposed to the crime, violence or vandalism in the area is very important indicator providing the quality of living conditions. Living in unsecure area reduces the housing comfort and the price of living area tremendously therefore this is important indicator of quality of life related to housing environment.

The indicator measuring the share of total population exposed to the noise from neighbours or from the street represents important issue of quality of housing environment as living in noisy area has negative impact on comfort and human health. Noise pollution is one of the most difficult problems in urban areas and multi-flat houses. Pollution, grime or exposure to the other environmental problems represents the quality of housing environment and has direct impact on human health and living conditions. Large and comfortable houses in polluted environment does not provide for satisfactory living conditions and this is also being reflected by prices of living area in polluted regions and locations.

The proximity of public services such as schools and hospitals is important indicator of quality of life related with housing. The share of population satisfied with housing environment is a perceived indicator and also useful for assessment of quality of life related to housing. The satisfaction with housing environment is a subjective indicator capturing the extent to which people's perceived needs for services in the housing area are met in practice. This indicator is not being assessed and collected neither by EUROSTAT neither OECD statistical institutions.

\section{HOUSING EXPENDITURES BURDEN}

The housing cost overburden rate is an indicator of housing affordability. It is measured as the percentage of the population living in households where the total housing costs (net of housing allowances) represent $40 \%$ or more of their equivalised disposable income. This indicator is thus a measure of the housing costs effectively supported by households. This indicator is limited to European countries and relies on data from the EU-SILC survey. Housing costs, in the EU-SILC definition, refer to monthly costs and include actual rents paid, the costs of utilities (water, gas, electricity and heating), housing taxes and compulsory insurance, as well mortgage interest payments and regular maintenance and repairs by home owners while excluding the repayments of principal on mortgages.

This indicator is an imperfect proxy of the pressure of housing costs on the household budget: indeed, some middleand high-income households can decide to spend a large amount (40\% or more) of their disposable equivalised income for housing, without incurring any form of material deprivation.

Indicator representing the share of households enable to keep home adequately warm is very important indicator representing economic strain linked to dwelling. Especially this indicator is important in cold climate countries such as Easter Europe, including Lithuania as well.

The share of housing costs in disposable household income, cost also represents the economic strain linked to dwelling.

Indicator of inability to pay utility bills represents the economic strain of households and takes into account high prices for electricity, heat and water supply etc. compared to low income what is especially relevant to new EU member states situation.

\section{COMPARISON OF LITHUANIAN HOUSING INDICATORS}

Seeking to define the trends of housing indicators in Lithuania and to compare them with the same indicators in old EU member states and neighboring countries the Table II was developed representing the trends of the main housing indicators relevant to quality of life in Lithuania from 2005 to 2012. Lithuania has entered EU in 2004 therefore these trends also represent the impact of joining EU on quality of life in terms of housing in Lithuania.

As one can see from Table II the housing indicators related to quality of live in Lithuania were improving since 2005 however economic crisis of 2008 has negative impact on housing expenditures burden indicators such as housing cost overburden rate, inability to keep home warm, to pay bills. Indicators related with quality of housing and housing environment have positive trends during all investigated period. Comparing Lithuanian housing indicators with the same indicators in old EU member state one can noticed that in advanced developed countries such as Austria, Germany, France, Belgium, Netherlands etc. all housing indicators are lower indicating higher quality of housing, better environment of housing and lower housing expenditure rates with some exceptions.

Regarding overcrowding rates in 2012 the highest were observed in Romania (54.2\%), Bulgaria (47.4\%), Poland (47.2\%) and Hungary (47.1\%), while the lowest were seen in 
the Netherlands (1.7\%) and Belgium (2.2\%). The EU-27 average rate of overcrowding was $16.9 \%$ and in Lithuania significantly higher $-19 \%$. In the EU as a whole and in more than half of the EU countries the overcrowding rate is higher if single person households are excluded from the computation of the indicator. Overall in the EU-27, the overcrowding rate is higher for those who are at risk-of-poverty (i.e. people living in households where equivalised disposable income per person was below $60 \%$ of the national median) compared to the total population.

TABLE II: THE DYNAMICS OF HOUSING INDICATORS RELEVANT TO QUALITY OF LIFE IN LITHUANIA

\begin{tabular}{|c|c|c|c|c|c|c|c|c|}
\hline \multirow{2}{*}{ Indicators } & \multicolumn{8}{|c|}{ Years } \\
\hline & 2005 & 2006 & 2007 & 2008 & 2009 & 2010 & 2011 & 2012 \\
\hline Overcrowding rate, $\%^{2}$ & 52.8 & 53.5 & 52.5 & 49.9 & 49 & 46.4 & 19.5 & 19 \\
\hline $\begin{array}{c}\text { Housing deprivation rate by } \\
\text { number of item, } \% \\
\text { Share of total population } \\
\text { considering their dwelling as }\end{array}$ & 28.3 & 26 & 21.9 & 19.8 & 16.8 & 13.6 & 7.6 & 7.1 \\
\hline $\begin{array}{c}\text { too dark, } \% \\
\text { Crime, violence or vandalism }\end{array}$ & 12.3 & 11.2 & 10.6 & 10.2 & 8.8 & 8.2 & 7.8 & 7.0 \\
\hline in the area, $\%$ & 9.0 & 7.8 & 7.1 & 4.9 & 6.6 & 5.2 & 4.8 & 5.0 \\
\hline $\begin{array}{l}\text { Noise from neighbours or from } \\
\text { the street, } \%\end{array}$ & 19.8 & 20.0 & 18.5 & 16.6 & 16.1 & 14.1 & 13.9 & 13.3 \\
\hline $\begin{array}{l}\text { Pollution, grime or other } \\
\text { environmental problems, } \% \\
\text { The housing cost overburden }\end{array}$ & 14.0 & 13.8 & 15.4 & 12.7 & 13.8 & 12.1 & 14.2 & 14.6 \\
\hline $\begin{array}{c}\text { rate, } \% \\
\text { Inability to keep home }\end{array}$ & 9.0 & 6.9 & 4.8 & 4.8 & 5.5 & 10.6 & 11.1 & 8.9 \\
\hline $\begin{array}{l}\text { adequately warm, } \% \\
\text { The share of housing costs in } \\
\text { disposable household income, } \\
\text { cost, } \%\end{array}$ & 34.8 & 27.6 & $22 ., 4$ & 22.1 & 24.1 & 25.1 & 36.2 & 34.1 \\
\hline Inability to pay utility bills, $\%$ & 20.7 & 13.8 & 8.9 & 5.9 & 8.5 & 11.1 & 11.8 & 12.6 \\
\hline
\end{tabular}

In Lithuania the dynamics of overcrowding rate has more than halved since 2005 and this is very positive trend similar to other house quality indicators analysed in Lithuania.

In 2012, the housing deprivation rate in the EU was 5.5\% and it was more than double that for the population that was at risk of poverty. In Lithuania housing deprivation rate was $7 \%$ and was slightly higher as EU-27 average. The highest rates for the total population were exhibited by Romania (25.9\%) and Latvia (17.9\%). The housing deprivation rate was below $1 \%$ of the total population in Finland and the Netherlands. In Romania $53.0 \%$ of the population that was at-risk-of poverty faced housing deprivation.

In 2012 in all EU 16.3\% were found to suffer from one of the dwelling problems, $4.1 \%$ suffered from two, $0.9 \%$ suffered from three and $0.3 \%$ suffered from all four of dwelling problems (i.e. leaking roof/damp walls/floors/foundation or rot in window frames and accommodation being too dark and no bath/shower and no indoor flushing toilet for sole use of the household). At the EU-level, the main housing problem was found to be a 'leaking roof' (i.e. leaking roof or damp walls, floors or foundation, or rot in window frames of floor') (15.5\%), followed by 'darkness of the dwelling' (6.8\%) while less than $3.5 \%$ of the EU population lacked basic sanitary facilities (i.e. lack of bath/shower or indoor flushing toilet). Exceptions to this EU trend are Bulgaria, Estonia, Latvia, Lithuania and Romania, where sanitary problems were found to be equally or more frequent than the other two housing problems mentioned above.

The housing deprivation rate by number of item has reduced in Lithuania by 4 times during 2005-2012.

Share of total population considering their dwelling as too dark has halved in Lithuania during 13 years and today $7 \%$ percent of population is considering their dwellings as too dark. The EU-27 average makes $6,1 \%$ and is slightly lower. In This indicator in Latvia makes $10 \%$ and is the highest among EU-27 member states.

As regards indicators of housing environment in 2012 $15.3 \%$ of the EU-27 population perceived the area in which they live as being affected by pollution, grime or other environmental problems. At the country level, the figures ranged from less than $10 \%$ in Sweden, Spain, Finland and Denmark to over $40 \%$ in Malta. Rates were small in Croatia (7.3\%) and Norway (7.5\%). Crime and/or vandalism were perceived as a problem by $14.2 \%$ of the EU-27 population in 2011. At the country level, the rates were highest in Bulgaria (27.2\%), the United Kingdom (20.7\%) and Greece (20.1\%), while only $5 \%$ of the population in Lithuania and $6.3 \%$ in Poland considered this to be a problem. At the EU-27 level, the greatest difference of 2.8 percentage points between the total population and the population at-risk-of-poverty concerned both noise and crime, violence and vandalism, while the lowest difference (of 1.2 percentage points) concerned pollution.

Noise from neighbours or from the street was the problem $18 \%$ of total population in EU in 2012. In Lithuania this indicator makes $13.3 \%$ and is lower than EU average and among the lowest between EU member states. The highest indicators of noise are in Germany, Malta, Cyprus, Romania etc.

The dynamics of indicator of pollution, grime or other environmental problems was stable for Lithuania during 13 years period. It makes $14.6 \%$ and is similar to EU-27 average $(14.1 \%)$ in 2012. The highest rate is in Malta, Greece, Germany, Latvia.

As regards housing expenditures in 2012, an estimated 
$11.5 \%$ of the EU-27 population lived in households that spent more than $40 \%$ of their disposable income on housing. In Greece, Denmark, the United Kingdom, Germany and the Netherlands the housing cost overburden rate exceeded $14.0 \%$, while the lowest rates were reported by Cyprus $(2.7 \%)$ and Malta $(2.8 \%)$.

At EU-27 level the percentage of people whose housing costs exceeded $40 \%$ of their equivalised disposable income was around $11.5 \%$ for all age groups (people below the age of 18 , people in the age of 18-64, over the age of 65). However, this is not the same in all EU Member States. In ten Member States the elderly suffer more than the younger age groups in what regards housing cost affordability.

In Lithuania the housing cost overburden rate in 2012 made $8.9 \%$ and reached the level of year 2005. This indicator for Lithuania is lower than EU-27 average. Very high housing cost overburden rates are in Greece (33\%). In Romania, Bulgaria, Denmark, Germany etc. they are twice lower reaching $16 \%$.

Indicator of inability to keep home adequately warm in Lithuania made $34.1 \% \mathrm{i} 2012$ and was among the highest one. Just in Bulgaria this indicator is higher and makes $46 \%$. The EU-27 average make just $10 \%$ indicating that situation in Lithuania is alarming.

The share of housing costs in disposable household income in Lithuania reached $20 \%$ in 2012 and was similar to EU-27 average $-22 \%$. The highest indicators are in Denmark, Netherlands and Switzerland. In Lithuania this indicator was almost stable during 2005-2012 periods.

Inability to pay utility bills in 2012 made $12.6 \%$ in Lithuania. EU-27 average made just 9.9\%. The highest indicators for inability to pay utility bills are in Bulgaria, Romania, Latvia. The best indicators are in Denmark, Iceland, Switzerland, Netherlands therefore though the share of housing costs makes a large share of households disposable income in old EU member states their do not cause problems for population to pay such high utility bills because of average high disposable income comparing with new EU member states including Lithuania.

\section{CONCLUSION}

Measuring housing conditions and their effects on people's well-being is a complex task because there are very few comparable indicators.

An ideal set of indicators to measure housing conditions should provide information about the physical characteristics of the dwelling and the broader environmental characteristics of the areas where the dwellings are located (e.g. exposure to noise, indoor pollution, etc.) and housing costs that make up a large share of the household budget.

The proposed system of housing indicators relevant to quality of life includes housing quality, housing environment and housing cost burden indicators.

Some proposed indicators of housing are not being reported by European and OECD statistical institutions however are relevant for quality of life assessment.

Analysis of trends of housing indicators in Lithuania indicated positive trends in development of all housing quality indicators however some housing environment quality and housing expenditure burden indicators were stable during 2005-2012 year period.

Lithuania distinguishes from other EU member states by high housing expenditures indicators. Especially high indicator of inability to keep home adequately warm indicates very high burden of heating costs for Lithuanian households.

Though the share of housing costs in disposable household income in Lithuania is similar to EU-27 average - $22 \%$ the high indicator of inability to keep home adequately warm and the high indicators of inability to pay utility indicates that Lithuania distinguishes from other EU members states with high energy, water etc. supply prices and low disposable income.

Though housing quality indicators have significantly improved significantly during analysed 13 years period the other housing indicators (housing environment, housing expenditures burden) were stable during the same period.

The policies aiming at housing environment and housing expenditures burden indicators needs to be developed as in this areas Lithuania is far behind other EU member states and the pace of improvement is too slow.

\section{ACKNOWLEDGMENT}

This research is funded by the European Social Fund under the Global Grant measure (No. VP1-3.1-ŠMM-07-K-03-032).

\section{REFERENCES}

[1] V. Albouy, P. Godefroy, and S. Lollivier, "Une mesure de la qualité de vie" INSEE, France, Portrait Social, Paris, 2010, pp. 99-114.

[2] R. Boarini, M. Comola, F. D. Keulenauer, R. Manchin, and C. Smith, "The determinants of well-being in OECD countries," OECD Statistics Directorate Working Paper, Paris, 2010.

[3] P. Dolan, T. Peasgood, and M. White, "Do we really know what makes us happy? A review of the economic literature on the factors associated with subjective well-being," Journal of Economic Psychology, vol. 29, pp. 94-122, 2010.

[4] J. F. Helliwell and C. P. Barrington-Leigh, "Measuring and understanding subjective well-being," NBER Working Paper 15887, National Bureau of Economic Research, 2010.

[5] D. Kahneman and A. Deaton, "High income improves life evaluation but not emotional well-being," in Proc. the National Academy of Sciences, vol. 107, no. 38, pp. 16489-16493, 2010.

[6] D. Kahneman and A. B. Krueger, "Developments in the measurement of subjective well-being," Journal of Economic Perspectives, vol. 20, no. 1, pp. 19-20, 2006.

[7] D. Kahneman, E. Diener, and N. Schwarz, Well-Being the Foundations of Hedonic Psychology, New York: Russel Sage Foundation, 1999.

[8] E. Diener, J. F. Helliwell, and D. Kahneman, International Differences in Well-Being, New York: Oxford University Press, 2010.

[9] R. R. Lucas, "Long-term disability is associated with lasting changes in subjective well-being: Evidence from two nationally representative longitudinal studies," Journal of Personaility and Social Psychology, vol. 92 , no. 4, pp. 717-730, 2007.

[10] C. Bjornskov, "How comparable are the gallup world poll life satisfaction data?" Journal of Happiness Studies, vol. 11, pp. 41-60, 2010.

[11] A. Sen, "Personal utilities and public judgements: Or what's wrong with welfare economics," Economic Journal, no. 89, pp. 537-555, 1997.

[12] F. Reto and J. Garcia-Vega, "Quality of life in Mexico: A formative measurement approach," Applied Research in Quality of Life, 2012, vol. 7, no. 3, pp. 220-230.

[13] C. Balestra and J. Sultan, "Home sweet home: The determinants of residential satisfaction and its relation with well-being," $O E C D$ Statistics Directorate Working Papers (forthcoming), OECD, Paris, 2012. 
[14] M. Merkaš et al., "Quality of life and leisure activities: How do leisure activities contribute to subjective well-being?" Social Indicators Research, 2011, vol. 102, no. 1, pp. 80-97, 2011.

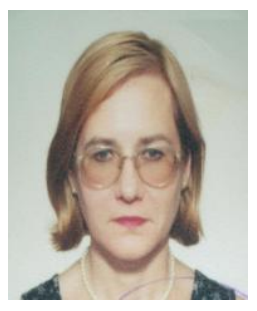

Dalia Streimikiene was born on 23 of March 1962 in Kaunas, Lithuania. She graduated from Kaunas University of Technology in 1985. In 1998 she maintained $\mathrm{PhD}$ in economics at Vilnius Gediminas Technical University. The major field of investigation is sustainable development, energy economics, environmental and energy policy.

Dalia Streimikiene works in position of professor at Mykolas Romeris University in Lithuania. She hold position of leading researcher at Lithuanian energy institute since 1985 . She is an author of more 50 papers in prestigious international scientific journals cited by ISI Web of Science, published several monographs in the field of sustainable development. The main research interests are related with sustainable development, social and environmental dimensions of sustainability.

Prof. Dr. D. Streimikiene is a member of International Association of Energy Economists (IAEE) and a member of Lithuanian Association of Economists. She is the editor in chief of International Scientific Journal Transformations in Bussiness and Economics and the vice editor in chief of International Scientific Journal Intellectual Economics. 